\title{
Citizens Perception of E-Government in Korea: Importance-Performance Analysis on Users Satisfaction and Behavioral Intention
}

\author{
Hayan Park \\ School of Public Affairs, \\ University of Science and Technology of China \\ Hefei, Anhui, 230026, China \\ Muhammad Firdaus Samijadi Ph.D. (Corresponding Author) \\ School of Humanities and Social Sciences, \\ University of Science and Technology of China \\ Hefei, Anhui, 230026, China
}

Received: May 25, 2021 Accepted: Jun. 16, $2021 \quad$ Online published: Jul. 1, 2021

doi:10.5296/jpag.v11i2.18677～URL: https://doi.org/10.5296/jpag.v11i2.18677

\begin{abstract}
The implementation of technological developments in the field of Information and Communication Technologies (ICT) have been carried out by many countries to help make government service delivery to their citizens better. E-government initiatives are developed to try and attain a higher level of efficacy in government service provision by utilizing the latest developments in ICTs to innovate and promote the interactions with citizens. E-government initiatives should not only be about putting forms, websites and services online, but should also provide a framework of options on how the government continues to improve their services and how to bring adjustments based on the users' demand. A citizen-centric study of how citizens perceive e-government services should help governments and future researchers adjust their initiatives accordingly. This study explores the citizens' perception of e-government in Korea by utilizing an Importance-Performance Analysis method and also seeks to identify which attributes of e-government can influence citizens' satisfaction and behavioral intentions. The result of the IPA indicates that technical support/feedback and real-time service provision are the main areas where e-government should focus on. Overall,
\end{abstract}


the IPA model indicates other factors that can influence satisfaction and behavioral intention, and a well-structured e-government plan based on the findings may as well enhance the specific aspect of e-government.

Keywords: Korea, E-government, Citizens Satisfaction, Behavioral Intentions

\section{Introduction}

\subsection{Research Background}

The implementation of technological developments in the field of Information and Communication Technologies (ICT) have been carried out by many countries in the past 50 years to improve government service provision and delivery to their citizens (Yoon et al., 2015). The main objective of research in the field of ICT implementation is to evaluate and understand the significance it brings to an organization. The purpose of the development in this area is to effectively take advantage of ICT resources and improve overall efficacy. The invention of the internet is one such technology that has given governments many new methods and opportunities to interact with their citizens. It would be imprudent given the possibilities the internet offers if countries do not utilize it to the fullest potential. Innovative concepts are continuously being adopted by governments to give a wider range of accessibility to e-government services from devices such as computers, laptops, smartphones, and other handheld devices which are widely being used by people in their daily lives. The conventional way of having access to a government service was limited to an office location and office hours, while e-government systems/services are more versatile and removes the condition of time and place with regards to accessibility within an area imbued with ICTs (Stratu-Strelet et al., 2021). Much research have been conducted with various approaches on e-government with the majority converging on the same concept characterizing e-government systems as making use of ICT to improve service provision to their citizens (Holden \& Fletcher, 2001; Muir \& Oppenheim, 2002; Evans \& Yen, 2006; Shareef et al., 2010; Reddick \& Norris, 2013; Samijadi, 2017). The advancement of technology innovation will continuously create more possibilities for citizens to access and absorb information and provide governments with more options on how to effectively implement these advancements to interact with their citizens. Burn \& Robins (2003) argue that e-government initiatives should not only be about putting forms, websites and services online, but should also provide a framework of options on how the government continues to improve their services and how to bring adjustments based on the users' demand. According to the United Nations E-Government Development Index (EGDI) and Electronic Participation Index (EPI), the Republic of Korea has consecutively been ranked amongst the top 3 for the past 10 years (UN, 2020). This feat has constantly been promoted by Korean government officials and the media. The characteristics of good e-government should strive for more transparency and accountability and should implement services that are more citizen-centric. Research that focuses on specific factors or attributes that influence users' satisfaction and behavioral intention when considering engaging in e-government services may provide governments with a clearer comprehension of the needs and demands of their citizens to improve their implementation strategies. Hence, this research will utilize an Importance-Performance 
Analysis (IPA) to explore how these attributes influence the perceptions of citizens in Korea when engaging in e-participation.

\subsection{Brief history of Korean e-government}

The concept of the Korean e-government initiative began in the late 1970s where they started to establish the foundation for their e-government plans. In the 1980s the Ministry of Government Administration and Home Affairs (MOHAGA) started utilizing and implementing ICT within the government according to their "National Backbone Computer Network' project. The goal of this project was to establish a high-speed communications network and to digitally store important government records. The project consisted of five national networks. The Information Super-Highway project that was initiated in 1993 led also to the establishment of the Ministry of Information and Communication (MIC). In the late 1990s, Public access to government information services started migrating online. The demand for a participatory government has given more momentum to the e-government implementation since 2002 and several specific objectives were set under the 2003 "Korea's E-Government Roadmap." In 2008 Korea further formulated the "National Informatization Basic Plan" and the "smart E-Gov Plan" in 2011. Since 2013 Korea has embraced Government 3.0 as the new paradigm and the purpose envisioned in this period is to deliver services that are designed and customized to the users' needs and demands, while also focusing on development engines to create new jobs (Chung, 2015). While e-government is mainly regarded as an internet-based government or an online government, there are many other e-government technologies that are also being utilized in these environments that are non-internet based. For example, the use of PDAs, SMS text messaging, faxes, Bluetooth, CCTVs, tracking systems, RFID, biometrics, road traffic management, smart cards, and so on. Looking at today's world, the current Covid-19 pandemic has been a turning point for the governments of the world and challenged the way of life for mankind. This pandemic required the governments to take preventive measures to limit the spread of the virus by maintaining social distancing as such. Hence, forcing citizens and users to search for alternatives such as electronic services. The development level of the e-government infrastructure of a nation determines the availability of specific e-services in that country. This indicates that the higher the e-government infrastructure development is, the more possibilities to provide various e-services.

\section{Literature Review}

\subsection{Concept of e-government}

The definition of e-government can range from the use of ICT tools such as the internet or to simply provide services electronically. E-government initiatives are developed to try and obtain a higher efficacy in government service provision and delivery by utilizing new ICTs to innovate and increase government-citizens interactions (Layne \& Lee, 2001; Basu, 2004; Alshehri et al., 2012). The goal of the e-government initiative is to give citizens a way to access and interact with all governmental agencies and to provide various types of services through the utilization of information communication networks (AlMarabeh \& AbuAli, 2010; Dias, 2020); To reduce the cost and too add value to a successful e-government service 
implementation, governments need to be diligent when utilizing new technologies and communication tools to develop the necessary infrastructure (Setyono et al., 2019). Before moving on to the e-government adoption process, roadmaps and frameworks should be worked out to explain the rationale and the collective undertaking required for a successful execution of such initiatives (Tomor et al., 2019). Governments are trying to increase the success rate of e-government projects by adjusting their systems and services on how citizens can learn basic computer skills to better understand the possibilities of e-government. The information provided by newspaper columns, radio programs, tv shows and other traditional media is still necessary to increase awareness of citizens about e-government objectives. The information on the contents of e-government should locally be provided in the language understood widely by the majority of citizens to better understand ongoing e-government projects. The use of speech or pictures instead of written texts can also help to make sure that e-government channels are easy to follow (Bhatnagar, 2004; Almarabeh \& AbuAli, 2010).

\subsection{E-government Satisfaction}

E-government services are interactive services in which the government provides government-related information on the internet by utilizing advanced information, communication, and multimedia technologies. Citizens' satisfaction is a key indicator to measure and assess the performance of e-government services (Jinhua, Yong, and Peng, 2010). Citizens' satisfaction shows the amount of satisfied users and the degree of satisfaction with regards to their expectations (Zaim et al., 2010). This is a citizen assessment through e-government service experience (Howard \& Sheth, 1969), which means citizens' awareness of e-government services is assessed by the advantages of transaction, transparency, and interaction (Saha, 2008). In an e-government service assessment, citizens show their impressions on the quality and user-friendliness of the provided e-government services (Farelo \& Morris, 2006). According to Korsten \& Bothma (2005), an indication of an effective e-government, is to provide the latest content and be comprehensive. In the end, e-government service satisfaction includes the quality and satisfaction factors of citizens' (Kaisara \& Pather, 2009). As the quality of e-government services improves, the efficiency and satisfaction of e-government increases. Therefore, the satisfaction level of e-government services by citizens is used to reflect the overall quality and operational level and to evaluate the performance of citizen-centered e-government services (Horan, Abhichandani, and Rayalu, 2006). In addition, satisfied users of e-government services are more likely to speak favorably to others and continue using the same e-government services in the future.

\subsection{Factors affecting the satisfaction of e-government}

The satisfaction of e-government services among citizens can be affected by many factors. Jinhua, Yong, and Peng (2010) value citizen expectations, ease of use, usefulness, quality and ability to use, civil satisfaction, government image, citizens' confidence, and civic engagement as factors that affect e-government service satisfaction. Amongst these, citizens expect an overall high-quality before engaging these e-services (Di Nisio \& Di Battista, 2010). Citizens' expectations for good quality and meeting personal needs, and the level of service expectations of citizens has a significant impact on service satisfaction (Spreng and 
Page, 2001). According to Wirtz \& Bateson (1999) the inconsistency and vagueness in citizens' expectations have a great influence on the service satisfaction process, and in many countries, citizens have high expectations for e-government in terms of service delivery and civic engagement (Kaisara \& Pather, 2009; Napitupilu \& Adiyarta, 2019). Halaris, Magoutas, and Papadomichelaki (2007) argue that quality, site quality (website usefulness and interface characteristics), technical features of websites, and the quality aspects related to conventional government services are important factors. Papadomichelaki, Magoutas and Halaris (2006) focuses on three areas: content, system, and organization. It covers information and quality related to the presentation, including accuracy, punctuality, refinement, relevance, and simplicity. The system identifies quality with ease of access, dependability, completeness, functionality, regulation, and security. Alanezi, Kamil, and Basri (2010) use website design, reliability, responsiveness, security, personality, and ease of information. As such, there are various factors that can influence the satisfaction of e-government services, but the types and quality of service are especially important (Rambe, 2017).

\subsection{Behavioral Intention}

The definition of Ajzen and Fishbein (1980) on behavioral intention is the level to which someone has developed a volitional agenda to carry out or not carry out a certain future behavior. According to their theory of reasoned action (Fishbein and Ajzen, 1977), behavioral intention is the driving element of inconsistent behavior and is closely related to the action itself (Jang and Feng, 2007). Some arguments still debate the relationship between behavioral intentions and the actual undertaking, but there appears to be a general consensus that behavioral intention is a practical construct for anticipating future behavior (Ouelette \& Wood, 1998). A high level of understanding the motivation of commending post-usage behavioral intentions such as saying something good about e-government systems/ or services, recommend utilizing e-government to others and continue to utilize these systems/ or services can provide practical suggestions for e-government initiatives. Another variable that is greatly correlated to behavioral intentions is satisfaction. Satisfaction is argued to be one of the key perquisites of post-usage behavioral intentions (Oliver, 1980, 1999). However some previous studies argue that the elements affecting users satisfaction are not always in compliance with factors affecting their behavioral intentions. Therefore, we can utilize this pragmatic need to explore the impact of e-government attributes on user satisfaction and behavioral intentions.

\subsection{Information-Related Attributes}

Information construct is defined as the medium that should provide citizens with content either by the government or by other users (Al-Dalou \& Abu-Shanab, 2013). The implementation of e-government is to give their citizens an abundance of content on policy, laws, news, regulation, etc. At the core of e-government, information plays a crucial part in the e-participation experience (Reffat, 2003). The type of information may influence users' satisfaction and post-usage behavioral intention. If the government supplies abundant, intelligible, relevant, and specific information to their citizens, this in turn will generate a higher intention to participate in e-government. Research have also argued that circulating 
and providing more information about government initiatives may lead to increased efficiency, flexibility and transparency of the e-participation process. These initiatives according to Macintosh and Whyte (2006) can produce an increased rate of citizens' e-participation in government activities. This study classified information-related attributes to include 3 attributes: 1) amount of information, this indicates the type of information that should be accessible by the public. A wider scope of available information at the disposal of the user has the possibility to influence satisfaction; 2) depth of the information indicates the profoundness of information; 3) update of information, this attribute indicates how often citizens would like to have new information provided to them. Ultimately information can provide an important indicator to e-government initiative based on the results from this study.

\subsection{Usability-Related Attributes}

Usability is an attribute that should reflect the simplicity of an online service (Nelson, 1994; Flavian et al., 2006). In prior studies, usability is defined as the ability to effortlessly use an innovation and is paired with ease of use (Venkatesh and Davis, 1996). Other definitions of usability from various literature all have the same concept in common, the simplicity of understanding and using an online service. Usability is an essential attribute of an online service (Massey et al., 2007). And according to Flavian et al. (2006) usability is probably the most significant factor in which users assess a system/ service and is arguably the most important determinant of service quality and user satisfaction. In the subject of e-government, transactional services demand too many steps, hence, transactions may likely be considered by users as being difficult with poor usability. Venkatesh \& Davis (1996) mentioned that citizens may possibly see usability as an obstacle that can affect the perceived efficacy of the overall service. But the evidence in later research by Venkatesh (1999) indicated the significance of usability even over efficacy considerations and showed that usability plays an even more critical role in the perception of efficacy to such an extent that poor usability decreases effectiveness that could lead to a rejection behavior (Venkatesh, 1999). Other previous literature on services such as Meuter et al. $(2000,2005)$ claims that users are more likely to engage and seemed to be more satisfied with simple, easy to use self-services. Prior research identified usability as an important requirement for acceptance in various scenarios both among organizations and users (Venkatesh \& Davis, 1996; Thong, 1999; Venkatesh \& Brown, 2001; Hong et al., 2002; Brown et al., 2006; Flavian et al., 2006). More literature on citizens' adoption of e-government discovered that usability is a key factor for various e-government services (Wang, 2003; Gilbert et al., 2004; Becker, 2005). Provided the fact that usability represents citizens' evaluation of the convenience and the simplicity of the process with the means to access transactional e-government services, it may represent a critical attribute of the main service. Usability is anticipated to be significant because users have different levels of technical knowledge. Hence for this research, usability related attributes include the following 4 items: 1) Accessibility, which indicates the availability and how easy users can gain access to e-government system/ services in general; 2) Interface smoothness indicates the responsiveness of the service in term of loading time, transaction fluidity, etc.; 3) Ease of use indicates how easy it is to learn and utilize the provided service; 4) Speed indicates how fast the system performs, data processing or how fast users can engage 
and disengage. The attributes were all designed for maximum effectiveness in measuring the importance and performance value.

\subsection{Reliability-Related Attributes}

Reliability indicates how well all the service functions work, and how promptly issues that arise are being solved (Wimmer et al., 2010). It further indicates the citizens' evaluation of the services on government website performance (Omar et al., 2011; Panadomichelaki \& Mentzas, 2012). Parasuraman et al. (2005) regards reliability as a needed factor to online service quality, because proper technical functioning of the site can precisely determine the outcome of the service, and any interference will decrease service efficacy and bring inconvenience to the users. Within the realm of e-government, transactional services on government websites have shown the importance of reliability in explaining citizens' perceptions and have been supported by practical evidence (Wimmer et al., 2010; Papadomichelaki \& Mentzas, 2012; Osman et al., 2014). Security to a certain degree is directly related to reliability and may affect the perception of reliability. Security features when engaging in e-government is defined to what extent government websites protects itself and its users from online threats and attacks (Tan et al., 2013). As expected, in regards to online public services, security is one of the most important features to users, more specifically public services that involve financial transactions or personal privacy (Horan et al., 2006; Hu et al., 2014; Blut, 2016). Security breaches on government websites will not only prevent citizens from engaging in e-government services but may also increase their discontentment with the quality of e-government systems (Stibbe, 2005; Tassabehji et al., 2007). Past literature have also indicated that citizens' perception of security provison is an important factor for the adoption of e-government, (Wimmer et al., 2010; Shareef et al., 2011; $\mathrm{Hu}$ et al., 2014). Reliability in this study includes 3 attributes; 1) Reliability which indicates how stable and trustworthy the citizens perceive e-government system and services; 2) Transparency which indicates the extent to which government policy strives for openness and accountability; 3) Security indicates to what extent the government implemented security features into their systems to protect all stakeholders. These attributes were selected because of the correlation between their definition and that they all aim for the same objective.

\subsection{Technical-Related Attributes}

Literature focused on service delivery has recognized the significance of customer service support in online service delivery (Parasuraman \& Zinkhan, 2002; Surjadjaja et al., 2003; Froehle and Roth, 2004). Technical support can affect users' commitment (Parasuraman \& Zinkhan, 2002) and contentment (Meuter et al., 2000). Real-time support from a competent customer service official is peculiarly effective in e-service operations. The power of online support is commonly associated with technology-induced change caused by the internet on how users interact and how organizations communicate with their customers (Parasuraman \& Zinkhan, 2002). Concerning e-government, technical support can be provided in a variety of ways. When users are unable to acquire a one-on-one support while using e-government services online, it is imperative to provide a functional design and delivery of online technical support. Users may require different levels of technical support based on their own level of 
understanding when using e-government services. Technical support services are described as an essential part of supporting services. With a satisfactory technical support, citizens are more likely to start utilizing or continue utilizing e-services. Past literature also claim that individuals vary in their abilities to operate technologies and some may need the assistance of others to be able to perform a task (Thatcher et al., 2008). Hence computer support provisions ensures that technology becomes easy to use. Online users commonly need technical support to assist them with a variety of issues, and this claim is further supported by Kiesler et al., (2000) and indicates that technical support is crucial for users at home. Therefore, in this study we incorporated Technical support and includes 2 attributes; 1) Technical support attribute indicates the extent to which e-government has provided technical support into their systems; 2) Real-time service provision indicates whether the provided service is satisfactory for the users. These attributes were selected because of their relations with each other in terms of technical support.

\subsection{Publicity-Related Attributes}

Publicity is a concept that has often been misunderstood by many people and even some scholars. And it is commonly mistaken to be public relations or even advertising. Bardi (2008) states that publicity is "the publishing of articles in the mass media and this activity does not necessarily translate to public relations". He ends by stating that publicity is merely a tool of public relations. The aim of publicity is to create awareness through available channels by providing news information about an organization and its products and services. Similar to marketing e-government needs to utilize the available tools to provide the necessary information and updates about their projects and initiative to raise awareness amongst their citizens. A well-informed public may increase the likelihood of citizens engaging in e-government. A well-designed publicity strategy can optimally provide new updates or critical information to the public. Publicity in this research is measured with 2 attributes: 1) Publicity which should indicate how citizens perceive this service if incorporated into e-government implementation; 2) Design and Construction indicate to the extend which measurement government have undertaken to provide a coherent service in raising awareness. Hence, this study incorporates these attributes as a form of measurement.

\section{Methodology}

\subsection{Research Measurement}

Based on a thorough literature review, a self-administered questionnaire was developed for this study. The questionnaire was administered in Korean, the official language of Korea, and separated into specific sections. The first section was designed to establish a baseline on e-participation. This is followed by a section for importance and a section for performance questions. The next section asked questions on satisfaction and behavioral intention. The following section is for perceived advantages and the final section is for the demographics. The questionnaire is composed of 48 questions in total. To measure the importance-performance of e-government systems and services we asked the respondents to rate each of the attributes when considering e-government usage and self-evaluation after e-government usage. The measurement utilized a 7-point Likert scale where $1=$ Not 
Important and 7 = Extremely Important. A total of 14 e-government attributes were carefully designed for this study based on the relevant literature and classified into five constructs: Information related attributes include 3 items: the amount of information, depth of information, update information; Usability related attributes include 4 items: accessibility, interface smoothness, ease of use, speed; Reliability related attributes include 3 items: reliability, transparency, security features; Technical attributes includes 2 items: technical support and feedback, real-time service provision and Publicity related attributes includes 2 items: publicity, design, and construction. The next section measured respondents' satisfaction and intention. All of these items were measured using a 7-point Likert scale, where $1=$ Totally disagree and $7=$ totally agree. In order to measure, we modified questions from Oliver (1997); Zeithaml et al. (1996); Zheng and Schachter (2016).

\subsection{Data Collection}

The initial method of survey data collection was through simple convenience sampling and snowball (chain-referral) sampling (Flyvbjerg, 2012). This sampling technique is a primary sample method and can also be used as part of a more complex sampling method. The sample target was limited to the residents in the Republic of Korea. The questionnaires were randomly distributed online, the total accepted sample size of this research was $263(n=263)$ valid responses.

\subsection{Analysis}

In order to analyze the collected data we utilized an importance-performance analysis (IPA) followed by multiple regression tools. The nature of an IPA is to integrate the measurements of attribute importance and performance into an easy to follow two-dimensional grid. This type of analysis can provide clear instruction for determining resource planning and allocation (Martilla and James, 1977; Oh, 2000; Liu \& Jang, 2009). In this research, the median values of the importance and performance ratings, used as the crossing point to project the IPA grid into four quadrants. Martilla and James (1977) stated the measurement for the central tendency is advised. Median values are better suited to means because a true interval scale may not be viable. The placement of the vertical and horizontal axes on the grid is based on evaluation, which translates to the usefulness of this approach which is set in determining relative, rather than absolute levels of importance and performance. Before moving on to the multiple regression analysis, the authors verified the reliability and validity of the constructs with a confirmatory factor analysis (CFA) in IBM AMOS 21.0. Later on, with the use of SPSS 21 a stepwise multiple regression analysis was carried out to test the effects of information, usability, reliability, technical support and publicity attributes on satisfaction and behavioral intentions. Users' satisfaction and behavioral intentions were then regressed independently against the performance of information, usability, reliability, technical support, and publicity. The samples of the tested models (Ex. Information) are revealed as follow:

$$
\begin{gathered}
Y_{s}=\beta_{0}+\beta_{1} X_{1}+\beta_{2} X_{2}+\cdots+\beta_{n} X_{n}+\varepsilon \\
Y_{b i}=\beta_{0}+\beta_{1} X_{1}+\beta_{2} X_{2}+\cdots---\beta_{n} X_{n}+\varepsilon
\end{gathered}
$$


where Ys denotes users satisfaction, obtained through the mean of the two-item measurement score; Ybi denotes users behavioral intention, obtained through the mean of the three-item measurement score; $\mathrm{X} 1-\mathrm{Xn}$ are the variables, representing the individual information related attributes; $\beta 0$ is the constant, $\beta 0-\beta \mathrm{n}$ are the regression coefficients of the independent variables; and $\varepsilon$ denotes the random error. The simulations of regression such as normality, constant variance, and linearity were examined before the regression analyses. Attribute correlations and multicollinearity were also examined in the analysis.

\section{Results}

\subsection{Demographic Profile}

Among the 263 valid responses, male accounted for $51.7 \%$, female $46.4 \%$ while 5 of the respondents did leave an answer for gender. The age distribution of the respondents was $31.6 \%$ aged between 35-44 years old, followed by $28.9 \%$ aged between $25-34$ years old and $26.2 \%$ was aged 45-54 years old. The education level indicated that $42.2 \%$ of the respondent had some college education without obtaining a degree, while $32.7 \%$ answered with having a bachelor's degree. This indicates that the education level of the respondents in this study is quite high.

Table 1. Demographic profile of respondents

\begin{tabular}{llrr}
\hline Variable & & Count & Percentage \% \\
\hline Gender & Male & 136 & 51.7 \\
& Female & 122 & 46.4 \\
Age & No answer & 5 & 1.9 \\
& <18 years & 6 & 2.3 \\
& 18-24 years & 12 & 4.6 \\
& 25-34 years & 76 & 28.9 \\
& 35-44 years & 83 & 31.6 \\
Education & 45-54 years & 69 & 26.2 \\
& 55-64 years & 15 & 5.7 \\
& $>65$ years & 1 & 0.4 \\
& No answer & 1 & 0.4 \\
& Less than High School & 7 & 2.7 \\
& High School Diploma & 41 & 15.6 \\
& College, but no Degree & 111 & 42.2 \\
& Bachelor Degree & 86 & 32.7 \\
& Graduate Degree(s) & 18 & 6.8 \\
& Less than 20,000,000 & 40 & 15.2 \\
& 20,000,000-34,999,999 & 71 & 27.0 \\
& 35,000,000-49,999,999 & 59 & 22.4 \\
& 50,000,000-69,999,999 & 49 & 18.6 \\
& 70,000,000-99,999,999 & 21 & 8.0 \\
& More than 100,000,000 & 17 & 6.5 \\
& No answer & 6 & 2.3 \\
\hline
\end{tabular}




\subsection{Importance-Performance Analysis}

\subsubsection{Importance Attributes}

Table 2. shows the attribute importance in rank and score. The attributes shows that the average score is above six, indicating that these attributes are quite important when users consider using e-government system/ services. The five highest-scoring attributes for importance were reliability, security features, ease of use, accessibility, and speed. The rankings also show the important positions of reliability-related and usability-related attributes in users' decision-making regarding e-government usage. The five least important attributes were publicity, design, and construction, amount of information, depth of information, and transparency Publicity related attributes and information related attributes make up for four of the five least important factors, suggesting that users do not have high expectations from publicity and information related attributes from using e-government systems/ services. However, it is imperative to understand that the IPA method determines relative, rather than absolute, levels of importance. Therefore, when we describe the results of the importance ranking, we should not come to the absolute conclusion that publicity and information attributes are not important to users when considering using e-government. These attributes when compared to other e-government attributes mentioned in this study are simply less important.

Table 2. Importance of e-government attributes

\begin{tabular}{llccr}
\hline Rank & Attributes & N & Mean & Std.Dev. \\
\hline 1 & Reliability & 263 & 6.601 & .9789 \\
2 & Security Features & 263 & 6.563 & 1.0351 \\
3 & Ease of Use & 263 & 6.521 & 1.0107 \\
4 & Accessibility & 263 & 6.510 & .9526 \\
5 & Speed & 263 & 6.422 & 1.0950 \\
6 & Interface Smoothness & 263 & 6.380 & 1.0912 \\
7 & Real-time Service Provision & 263 & 6.289 & 1.1459 \\
8 & Update of Information & 263 & 6.266 & 1.2096 \\
9 & Technical Support/Feedback & 263 & 6.243 & 1.1399 \\
10 & Transparency & 263 & 6.232 & 1.2461 \\
11 & Depth of Information & 263 & 5.992 & 1.2601 \\
12 & Amount of Information & 263 & 5.817 & 1.3496 \\
13 & Design and Construction & 263 & 5.555 & 1.4074 \\
14 & Publicity & 263 & 5.414 & 1.5700 \\
\hline
\end{tabular}

Cronbach's alpha: 0.936

\subsubsection{Performance Attributes}

Table 3. lists the attribute performance ranks and scores. The mean score of the overall performance was 5.394, indicating that the attributes for e-government usage mentioned in this study in general did well in terms of performance. The top five attributes were reliability, speed, security features, Interface smoothness, and accessibility. These rankings show that 
e-government should provide a well-designed reliability and usability related features. The five lowest were publicity, design and construction, real-time service provision, depth of information, and amount of information. Most of these are related to publicity and information attributes, indicating that there is room for e-government systems/services to make improvements on these features to improve the utilization experience.

Table 3. Respondents Assessment for Perceived Performance of E-government

\begin{tabular}{llccr}
\hline Rank & Attributes & N & Mean & Std.Dev. \\
\hline 1 & Reliability & 263 & 5.631 & 1.3496 \\
2 & Speed & 263 & 5.589 & 1.4056 \\
3 & Security Features & 263 & 5.570 & 1.4442 \\
4 & Interface Smoothness & 263 & 5.551 & 1.4129 \\
5 & Accessibility & 263 & 5.510 & 1.5155 \\
6 & Update of Information & 263 & 5.449 & 1.4210 \\
7 & Ease of Use & 263 & 5.445 & 1.5145 \\
8 & Transparency & 263 & 5.414 & 1.3561 \\
9 & Technical Support/Feedback & 263 & 5.380 & 1.4033 \\
10 & Amount of Information & 263 & 5.350 & 1.3190 \\
11 & Depth of Information & 263 & 5.331 & 1.3623 \\
12 & Real-time Service Provision & 263 & 5.312 & 1.5610 \\
13 & Design and Construction & 263 & 5.110 & 1.4799 \\
14 & Publicity & 263 & 4.867 & 1.6787 \\
\hline
\end{tabular}

Cronbach's alpha: 0.973

\subsection{IPA Results}

As shown in Figure 1, two attributes, (10) Technical support/ feedback and (11) Real-time service provision were sorted in the "concentrate here" quadrant. This shows that users find technical support/ feedback and real-time service provision as very important, but e-government performances were not satisfactory. Therefore, these two attributes are important factors that e-government should attempt to improve straightaway. Eight e-government attributes were designated into the "keep up the good work" quadrant: (3) transparency, (4) Update of information, (5) interface smoothness, (6) speed, (8) Accessibility, (9) ease of use, (12) security features, (13) reliability. These attributes indicate that users are in general satisfied with the reliability and accessibility of e-government systems and services. These results indicate the common image of e-government towards users to provide reliable and accessible services to their citizens. These attributes may demonstrate the elemental and essential points for e-government satisfaction for continued usage and should be preserved. Four attributes were grouped in the "low priority" quadrant: (1) amount of information, (2) depth of information, (7) design and construction, (14) publicity. These attributes were assessed relatively low in terms of performance and users did not find them to be very important. These attributes can be elaborated further in e-government long-term development strategies and they show room for potential improvement for e-government system/ services in the future. When government management resources are abundant or adequate then the 
government can start to work on these attributes to improve and enhance overall citizens' perception of e-government even more. The "possible overkill" quadrant does not include any attributes. The IPA approach explains what it means when attributes are assigned in this quadrant as "overdoing the job" but in terms of improving users' satisfaction, no attribute can indeed be overdone.

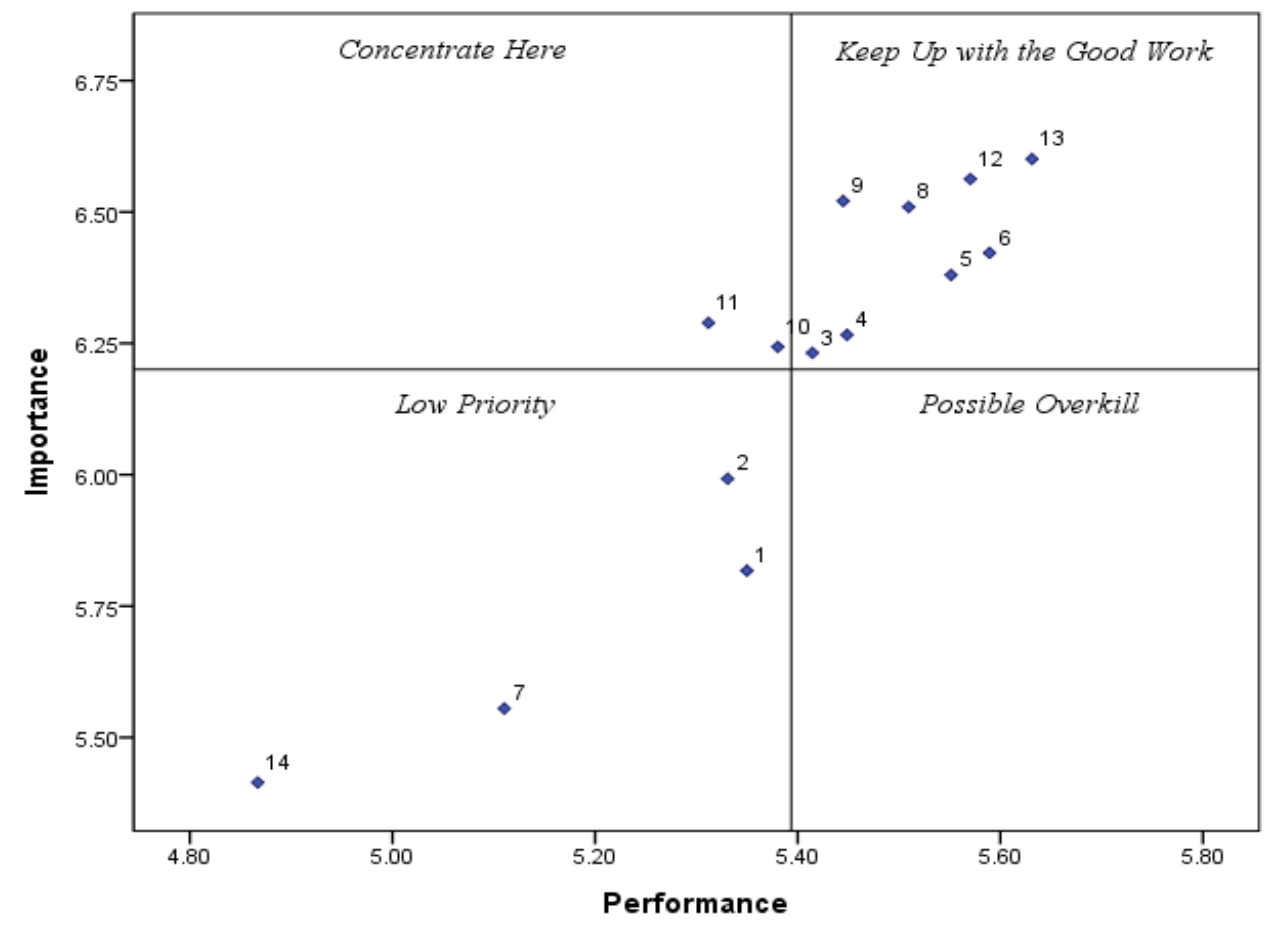

Figure 1. Importance-Performance Analysis Matrix

\subsection{Reliability and Validity}

The measurements for reliability was evaluated with Cronbach's alpha. The alpha values for the five constructs ranged between 0.785 and 0.956. As illustrated in Table 4, each construct surpassed the minimum requirement of 0.6 thus guaranteeing appropriate internal consistency (Hair et al., 1998). The validity of the constructs were also satisfied, all the items had high standardized factor loadings on their underlying constructs where values ranged between 0.5 and 0.9 and were all significant at 0.001 . Additionally, the average variance extracted (AVE) from all constructs but one, publicity attribute, did not exceed the minimum criteria of 0.50 , showing that the majority of the variance was explained by the constructs. Although it is widely considered that the AVE should be higher than 0.5 we can accept 0.4 , because Fornell and Larcker (1981) stated that if the AVE shows a value lower than 0.5 but composite reliability has a value higher than 0.6 which in this case has a value of 0.6095 , then the convergent validity of the construct is still acceptable (Lam, 2012). The indices for CFA also showed that the model was a good-fit $(\mathrm{CMIN}=208.644, \mathrm{CMIN} /$ d.f. $=2.939, \mathrm{CFI}=0.967$, NFI $=0.951$, TLI $=0.958$, RMSEA $=0.086$ ). The recommendations for RMSEA cut-off points have been significantly reduced in the last century until the early nineties. According 


\section{Macrothink}

Journal of Public Administration and Governance

ISSN 2161-7104

2021, Vol. 11, No. 2

to MacCallum et al. (1996) RMSEA in the range of 0.05 to 0.10 can be considered an indication of fair fit. Later on it was then thought that an RMSEA of between 0.08 to 0.10 provides a mediocre fit and below 0.08 shows a good fit (MacCallum et al, 1996).

Table 4. Result of Confirmatory Factor Analysis

\begin{tabular}{|c|c|c|c|}
\hline Constructs and indicators & $\begin{array}{c}\text { Standardized factor } \\
\text { loadings }\end{array}$ & $\begin{array}{c}\text { Cronbach's } \\
\text { alpha }\end{array}$ & $\overline{\mathbf{A V E}}$ \\
\hline Information-related attributes & & .893 & .5230 \\
\hline I1: Amount of Information & 621 & & \\
\hline I2: Depth of Information & 685 & & \\
\hline I3: Update of Information & .845 & & \\
\hline Usability-related attributes & & .956 & .6965 \\
\hline U1: Interface Smoothness & .845 & & \\
\hline U2: Speed & .832 & & \\
\hline \multirow{2}{*}{$\begin{array}{l}\text { U3: Accessibility } \\
\text { U4: Ease of Use }\end{array}$} & .821 & & \\
\hline & .840 & & \\
\hline Reliability-related attributes & & .893 & .6226 \\
\hline R1: Transparency & .758 & & \\
\hline R2: Security Features & .792 & & \\
\hline R3: Reliability & .816 & & \\
\hline Technical-related attributes & & .906 & .6733 \\
\hline \multirow{2}{*}{$\begin{array}{lr}\text { T1: } & \text { Technical } \\
\text { Support/Feedback } & \\
\text { T2: Real-time } & \text { Service } \\
\text { Provision }\end{array}$} & .827 & & \\
\hline & .814 & & \\
\hline Publicity-related attributes & & .785 & .4426 \\
\hline P1: Design and Construction & .747 & & \\
\hline P2: Publicity & .572 & & \\
\hline Satisfaction & & 949 & .6964 \\
\hline $\begin{array}{l}\text { S1: E-gov } \\
\text { S2: Usage }\end{array}$ & .834 & & \\
\hline & .835 & & \\
\hline Behavioral Intention & & 951 & .7106 \\
\hline \multirow{2}{*}{$\begin{array}{l}\text { B1: Use } \\
\text { R2. Recommend }\end{array}$} & .816 & & \\
\hline & .842 & & \\
\hline B3: WOM & .870 & & \\
\hline \multicolumn{4}{|c|}{$\begin{array}{l}\begin{array}{l}\text { Goodness-of-fit } \\
\text { indices }\end{array} \\
\text { CMIN }=208.644, \mathrm{P}=.000, \mathrm{CIM} / \mathrm{d} . \mathrm{f}=2.939, \mathrm{CFI}=.967, \mathrm{TLI}=.958, \mathrm{NFI}=.951, \\
\text { RMSEA }=.086\end{array}$} \\
\hline
\end{tabular}

Extraction method: principal component analysis

Rotation method: varimax with Kaiser normalization

Rotation converged in 3 iterations.

\subsection{E-government Attributes Influencing Satisfaction}

In order to discover the attributes that influence users' satisfaction and behavioral intentions 
in e-government usage, we utilized a stepwise multiple regression analysis. Multicollinearity between independent variables was shown to be less than 10 with VIF indices between independent variables were 1.729 to 5.022 , and tolerance limits were 0.198 to 0.578 with no multicollinearity problem above 0.1. Table 5.3 summarizes the effects of information, usability, reliability, technical support, and publicity attributes on users satisfaction. For information related attributes, this study indicates that depth of information and amount of information were significantly related to users' satisfaction in e-government systems/ services. Based on the parameter estimates, depth of information appeared to be the most important contributor to satisfaction. Amount of information also appears to have a strong impact on satisfaction. Although the IPA results demonstrates that users generally do not think about information attributes when considering using e-government, these information attributes do influence satisfaction. Maybe because citizens subconsciously already decided that e-government initiative is created to provide information to the general public, hence are expecting the government to provide it as such. In terms of usability related attributes, accessibility and ease of use were significantly related to users satisfaction. These two attributes demonstrate the importance of convenience and simplicity when designing and implementing e-government systems. For reliability-related attributes transparency and security features significantly influenced users satisfaction. As these attributes also scored very high in the IPA analysis. Technical related attributes also shows that it can significantly influence users satisfaction. In fact, particular attention should be given to technical support/ feedback and real-time services. These two attributes according to the IPA results indicate that technical support/feedback and real-time service is considered by the user a very important factor that may increase users' experience because it shows that citizens are most likely expecting a high-quality service if they may need help or assistance when engaging in e-government. It is also possible that when prospective new users are considering to use e-government systems/ services they need the assurance that it is able to provide the necessary assistance to enhance their online experience, especially when they need assistance. In terms of publicity-related attributes, 'design and construction' and 'publicity' shows that they can influence citizens' satisfaction. Although the results of importance of e-government attributes (table 5) showed that citizens' design and construction was ranked 13 and publicity ranked 14 , according to the parameter estimate, design and construction $(\beta=0.422)$ was the greatest contributor. In fact, particular attention should be given to the role of publicity-related attributes in affecting citizens' satisfaction. The attributes of e-government that affect citizens' satisfaction according to standardized parameter estimates are in order, design and construction $(\beta=0.422)>$ technical support/feedback $(\beta=0.393)>$ depth of information $(\beta=0.367)>$ ease of use $(\beta=0.345)>$ security features $(\beta=0.336)>$ transparency $(\beta=0.296)>$ accessibility $(\beta=0.280)>$ amount of information $(\beta=0.258)>$ real-time service provision $(\beta=0.198)>$ publicity $(\beta=183)$. 
Table 5. e-government attributes influencing citizens' satisfaction

\begin{tabular}{|c|c|c|c|c|c|c|}
\hline Predictors & $\begin{array}{c}\text { Parameter } \\
\text { estimates }\end{array}$ & $\begin{array}{l}\text { Std. } \\
\text { error }\end{array}$ & t-statistics & p-value & VIF & $\begin{array}{c}\text { Model } \\
\text { statistics }\end{array}$ \\
\hline $\begin{array}{l}\text { Information-related } \\
\text { attributes }\end{array}$ & & & & & & $\begin{array}{l}\mathrm{F}=70.183, \\
\mathrm{R}^{2}=.351\end{array}$ \\
\hline $\begin{array}{l}\text { Depth of } \\
\text { Information }\end{array}$ & .519 & .115 & 4.528 & .000 & 2.633 & \\
\hline $\begin{array}{l}\text { Amount of } \\
\text { Information }\end{array}$ & .337 & .106 & 3.180 & .002 & 2.633 & \\
\hline $\begin{array}{l}\text { Usability-related } \\
\text { attributes }\end{array}$ & & & & & & $\begin{array}{l}F=76.549, \\
R^{2}=.371\end{array}$ \\
\hline Accessibility & .403 & .159 & 2.538 & .012 & 5.022 & \\
\hline Ease of Use & .499 & .159 & 3.133 & .002 & 5.022 & \\
\hline $\begin{array}{l}\text { Reliability-related } \\
\text { attributes }\end{array}$ & & & & & & $\begin{array}{l}F=64.001, \\
R^{2}=.330\end{array}$ \\
\hline Transparency & .402 & .091 & 4.427 & .000 & 1.731 & \\
\hline Security Features & .476 & .095 & 5.037 & .000 & 1.731 & \\
\hline $\begin{array}{l}\text { Technical-related } \\
\text { attributes }\end{array}$ & & & & & & $\begin{array}{l}F=61.949, \\
R^{2}=.323\end{array}$ \\
\hline $\begin{array}{l}\text { Technical } \\
\text { Support/Feedback }\end{array}$ & .531 & .123 & 4.302 & .000 & 3.207 & \\
\hline $\begin{array}{l}\text { Real-time Service } \\
\text { Provision }\end{array}$ & .252 & .116 & 2.163 & .031 & 3.207 & \\
\hline $\begin{array}{l}\text { Publicity-related } \\
\text { attributes }\end{array}$ & & & & & & $\begin{array}{l}\mathrm{F}=58.843, \\
\mathrm{R}^{2}=.312\end{array}$ \\
\hline $\begin{array}{l}\text { Design and } \\
\text { Construction }\end{array}$ & .490 & .079 & 6.239 & .000 & 1.729 & \\
\hline Publicity & .194 & .072 & 2.698 & .007 & 1.729 & \\
\hline
\end{tabular}

\subsection{E-government Attributes Influencing Behavioral Intention}

In this section the result showed that Multicollinearity was less than 5 VIF 1.729 to 4.103, and tolerance was between 0.244 to 0.578 . This means that there were no reported multicollinearity problems, thus are not of concern here. Information-related attributes explained 38.6\% variables in behavioral intention. Usability-related attributes explained $39.5 \%$ variables, which is also the highest explanatory variables in this table. Similarly, the regression results for behavioral intentions are also described in Table 6. In the midst of e-government attributes affecting citizens' behavioral intention, interface smoothness emerged as the most important attribute. Unlike the satisfaction model, the behavioral intention model yield different results. Update of information, reliability were not significant in the satisfaction model. Which means, reliability and update of information did not influence citizens' satisfaction, whereas these two attributes shows that they have a significant effect on behavioral intention. The reliability significance above 0.05 was rejected, so reliability in this case was not significant. However, according to IPA results, reliability 
attribute scored highest in term of Importance-Performance. This proves that whether or not reliability influences citizens' satisfaction and behavioral intention it is an important factor for government to consider when designing or implementing e-government systems and services. Standardized parameter estimates show that interface smoothness $(\beta=0.466)>$ design and construction $(\beta=0.380)>$ technical support/feedback $(\beta=0.364)>$ security features $(\beta=0.281)>$ depth of information $(\beta=0.275)>$ update of information $(\beta=0.271)>$ publicity $(\beta=0.257)>$ real-time service provision $(\beta=0.247)>$ transparency $(\beta=0.227)>$ accessibility $(\beta=0.211)>$ amount of information $(\beta=0.189)$ have the influence of citizens' intentions of action in the order of that.

Table 6. E-government attributes influencing behavioral intentions

\begin{tabular}{|c|c|c|c|c|c|c|}
\hline Predictors & $\begin{array}{c}\text { Parameter } \\
\text { estimates }\end{array}$ & $\begin{array}{l}\text { Std. } \\
\text { error }\end{array}$ & t-statistics & p-value & VIF & $\begin{array}{c}\text { Model } \\
\text { statistics }\end{array}$ \\
\hline $\begin{array}{l}\text { Information-related } \\
\text { attributes }\end{array}$ & & & & & & $\begin{array}{l}\mathrm{F}=54.189, \\
\mathrm{R}^{2}=.386\end{array}$ \\
\hline $\begin{array}{l}\text { Depth of } \\
\text { Information }\end{array}$ & .385 & .129 & 2.984 & .003 & 3.577 & \\
\hline $\begin{array}{l}\text { Update } \\
\text { Information }\end{array}$ & .285 & .100 & 2.844 & .005 & 2.448 & \\
\hline $\begin{array}{l}\text { Amount of } \\
\text { Information }\end{array}$ & .245 & .104 & 2.539 & .019 & 2.711 & \\
\hline $\begin{array}{l}\text { Usability-related } \\
\text { attributes }\end{array}$ & & & & & & $\begin{array}{l}\mathrm{F}=85.053, \\
\mathrm{R}^{2}=.395\end{array}$ \\
\hline $\begin{array}{l}\text { Interface } \\
\text { Smoothness }\end{array}$ & .624 & .115 & 5.409 & .000 & 2.921 & \\
\hline Accessibility & .301 & .118 & 2.557 & .011 & 2.921 & \\
\hline $\begin{array}{l}\text { Reliability-related } \\
\text { attributes }\end{array}$ & & & & & & $\begin{array}{l}F=55.590, \\
R^{2}=.392\end{array}$ \\
\hline Transparency & .306 & .098 & 3.116 & .002 & 2.260 & \\
\hline Security Features & .394 & .121 & 3.252 & .001 & 3.170 & \\
\hline Reliability & .270 & .146 & 1.851 & .065 & 4.103 & \\
\hline $\begin{array}{l}\text { Technical-related } \\
\text { attributes }\end{array}$ & & & & & & $\begin{array}{l}F=67.848, \\
R^{2}=.343\end{array}$ \\
\hline $\begin{array}{l}\text { Technical } \\
\text { Support/Feedback }\end{array}$ & .488 & .121 & 4.046 & .000 & 3.207 & \\
\hline $\begin{array}{l}\text { Real-time Service } \\
\text { Provision }\end{array}$ & .312 & .114 & 2.743 & .007 & 3.207 & \\
\hline $\begin{array}{l}\text { Publicity-related } \\
\text { attributes }\end{array}$ & & & & & & $\begin{array}{l}F=66.021, \\
R^{2}=.337\end{array}$ \\
\hline $\begin{array}{ll}\text { Design } & \text { and } \\
\text { Construction } & \end{array}$ & .437 & .076 & 5.717 & .000 & 1.729 & \\
\hline Publicity & .270 & .070 & 3.868 & .000 & 1.729 & \\
\hline
\end{tabular}




\section{Discussion and Implications}

\subsection{Discussion}

We set out to discover the attributes that can influence citizens' satisfaction and behavioral intention when using e-government services. It was observed that from the 14 attributes selected for this study 10 attributes indicate to significantly influence citizens satisfaction and 12 attributes indicate to significantly influence behavioral intention to e-government usage. Information related attributes that influence satisfaction include Depth of Info and Amount of Info, but update of information does not influence satisfaction. Whereas these three attributes do influence behavioral intention. Usability related attributes show that Accessibility and Ease of use are important factors to influence citizens satisfaction and furthers show that interface smoothness and speed do not greatly affect satisfaction. Whereas only accessibility and interface smoothness shows to affect behavioral intention. Reliability related attributes indicate that transparency and security features will influence satisfaction but reliability does not affect satisfaction, but all three attributes can significantly affect behavioral intention. Technical related attributes show that technical support and real-time service do influence citizens satisfaction and behavioral intention. Both Publicity related attribute influence satisfaction and behavioral intention. These result may help government identify potential factors to consider when implementing e-government systems.

\subsection{Implication of this Research}

The design of this study is particular in the aim that it was designed to seek and understand the citizens perception on e-government in South Korea. South Korea has consecutively proven to be one of the top countries with a high e-government development index. Utilizing a quantitative research approach the findings and result may be of significance to government planning to design or improve their online service delivery. There are many factors that may influence their perception on using e-government systems. A high e-government development index does not automatically translate to high e-participation rate. In order to increase e-participation, we need study and understand the need and demand of the stakeholders. We sought out to discover which attribute the government can consider to adopt when attempting to increase e-participation and enhance online service delivery. The attributes mentioned in this study may enhance the satisfaction and behavioral intention of citizens to consider e-government utilization. We argue that comprehending citizens perception regarding the utilization of e-government services and systems may help researchers and other stakeholders understand the role of enhanced user experience and willingness to re-use the provided service and attempting to find out the underlying issues that cause low e-government usage. As results of our findings, we hope to highlight expected needs and demands from a citizens perspective. Thus, suggest that government and e-government related departments and institutes take adequate measurements to create a sustainable, efficient e-government strategy. Clear strategic guidelines, planning and instruction will be of great value to the improvisation of e-government. 


\section{Conclusion}

After an extensive literature review, we focused on investigating citizens perception in Korea We utilized an IPA approach to understand what attributes affect satisfaction and behavioral intention. More importantly, the influence of these constructs shows that there is a very strong level of behavioral intention when considering e-government utilization. The model suggests that the attributes, variables, and constructs all support one another. Therefore, it is suggested that government may consider improving or implementing these variables when attempting to increase online service delivery. The findings also provide new indications in the research area, that in order to understand the full scope of e-government and e-participation all the related tools should be fully explored. It can determine an exceptional foundation for researchers to conduct future research on other tools that can further enhance e-Government initiatives. This study has several implications for the government of South Korea and to some extent the rest of the world, from the IPA model where it clearly indicates the factors influencing satisfaction and behavioral intention, a well-structured e-Government plan can enhance all aspect of e-government. Thus, encouraging future direct or indirect attempts for incorporating the ideas set forth in this research. This study can be of service as a guideline or directional paper for the concerned parties and other governments who are evaluating or considering reviewing their e-government strategy. The government with more available resources could therefore continue researching and developing a more comprehensive e-government application suited for their specific needs.

\section{Limitations}

This research project like any other research project has its limitations. There is a possibility that the sample in this study might be somewhat biased towards the direction of respondents based on their ability to access the internet. Finally, the current sample size of 263 and might be considered quite small to be definitive for the research area. Citizens' perception of satisfaction and behavioral intention towards e-government systems and services needs further investigation in a different environmental setting and larger sample size.

\section{References}

Abu-Shanab, E. A. (2013). The relationship between transparency and e-government: An empirical support. Electronic Government and Electronic Participation-Joint Proceedings of Ongoing Research of IFIP EGOV and IFIP ePart 2021.

Al-Dalou, R., \& Abu-Shanab, E. (2013, May). E-participation levels and technologies. In The 6th International Conference on Information Technology (ICIT 2013) (pp. 8-10).

Alanezi, M. A., Kamil, A., \& Basri, S. (2010). A proposed instrument dimensions for measuring e-government service quality. International Journal of u-and e-Service, 3(4). https://doi.org/10.1109/ICOS.2011.6079243

Alshehri, M., Drew, S., Alhussain, T., \& Alghamdi, R. (2012). The Effects of Website Quality on Adoption of E-Government Service: AnEmpirical Study Applying UTAUT Model Using SEM. arXiv preprint arXiv:1211.2410.

Almarabeh, T., \& AbuAli, A. (2010). A general framework for e-government: definition 
maturity challenges, opportunities, and success. European Journal of Scientific Research, $39(1), 29-42$.

Azjen, I. (1980). Understanding attitudes and predicting social behavior. Englewood Cliffs.

Bardi, J. N. (2008). The role of advertising, publicity and public relations in theatre management in Nigeria. EJOTMAS: Ekpoma Journal of Theatre and Media Arts, 2(1-2).

Basu, S. (2004). E-government and developing countries: an overview. International Review of Law, Computers \& Technology, 18(1), 109-132. https://doi.org/10.1080/13600860410001674779

Becker, S. A. (2005). E-government usability for older adults. Communications of the ACM, 48(2), 102-104. https://doi.org/10.1145/1042091.1042127

Bhatnagar, S. (2004). E-government: From vision to implementation-A practical guide with case studies. Sage.

Blut, M. (2016). E-service quality: development of a hierarchical model. Journal of Retailing, 92(4), 500-517. https://doi.org/10.1016/j.jretai.2016.09.002

Brown, S. A., Venkatesh, V., \& Bala, H. (2006). Household technology use: Integrating household life cycle and the model of adoption of technology in households. The Information Society, 22(4), 205-218. https://doi.org/10.1080/01972240600791333

Burn, J., \& Robins, G. (2003). Moving towards e-government: a case study of organisational change processes. Logistics Information Management. https://doi.org/10.1108/09576050310453714

Chung, C. S. (2015). The introduction of e-Government in Korea: development journey, outcomes and future. Gestion et management public, 3(2), 107-122. https://doi.org/10.3917/gmp.034.0107

Dias, G. P. (2020). Determinants of e-government implementation at the local level: an empirical model. Online Information Review. https://doi.org/10.1108/OIR-04-2020-0148

Di Nisio, R., \& Di Battista, T. (2010). Customer satisfaction and loyalty assessment by means structural equation models. Electronic Journal of Applied Statistical Analysis: Decision

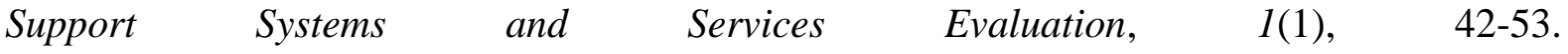
https://doi.org/10.1285/i2037-3627v1n1p42

Evans, D., \& Yen, D. C. (2006). E-Government: Evolving relationship of citizens and government, domestic, and international development. Government information quarterly, 23(2), 207-235. https://doi.org/10.1016/j.giq.2005.11.004

Farelo, M., \& Morris, C. (2006). Status of E-government in South Africa.

Fishbein, M., \& Ajzen, I. (1977). Belief, attitude, intention, and behavior: An introduction to theory and research.

Flavián, C., Guinalíu, M., \& Gurrea, R. (2006). The role played by perceived usability, satisfaction and consumer trust on website loyalty. Information \& management, 43(1), 1-14. https://doi.org/10.1016/j.im.2005.01.002

Flyvbjerg, B. (2012). Five Misunderstandings about Case Study Research, Corrected. Qualitative Research: The Essential Guide to Theory and Practice, London and New York: 
Routledge, 165-166.

Fornell, C., \& Larcker, D. F. (1981). Evaluating structural equation models with unobservable variables and measurement error. Journal of marketing research, 18(1), 39-50. https://doi.org/10.1177/002224378101800104

Froehle, C. M., \& Roth, A. V. (2004). New measurement scales for evaluating perceptions of the technology-mediated customer service experience. Journal of Operations Management, 22(1), 1-21. https://doi.org/10.1016/j.jom.2003.12.004

Gilbert, D., Balestrini, P., \& Littleboy, D. (2004). Barriers and benefits in the adoption of e-government. International Journal of Public Sector Management. https://doi.org/10.1108/09513550410539794

Hair, J. F., Anderson, R. E., \& Tatham, R. L. 8c Black, WC (1998) Multivariate data analysis.

Halaris, C., Magoutas, B., Papadomichelaki, X., \& Mentzas, G. (2007). Classification and synthesis of quality approaches in e-government services. Internet research. https://doi.org/10.1108/10662240710828058

Holden, S. H., \& Fletcher, P. D. (2001). A symposium on international applications of electronic government (E-Government): Research, practice, and issues-Introduction.

Hong, W., Thong, J. Y., Wong, W. M., \& Tam, K. Y. (2002). Determinants of user acceptance of digital libraries: an empirical examination of individual differences and system characteristics. Journal of management information systems, 18(3), 97-124. https://doi.org/10.1080/07421222.2002.11045692

Horan, T. A., Abhichandani, T., \& Rayalu, R. (2006, January). Assessing user satisfaction of e-government services: development and testing of quality-in-use satisfaction with advanced traveler information systems (ATIS). In Proceedings of the 39th Annual Hawaii International Conference on System Sciences (HICSS'06) (Vol. 4, pp. 83b-83b). IEEE. https://doi.org/10.1109/HICSS.2006.66

Howard, J. A., \& Sheth, J. N. (1969). The theory of buyer behavior (No. 658.834 H6).

Hu, G., Pan, W., Lin, H., Kang, K., \& Best, M. L. (2014). Study on the framework of e-government services capability: An empirical investigation. Social Science Computer Review, 32(1), 56-73. https://doi.org/10.1177/0894439313501614

Jang, S. S., \& Feng, R. (2007). Temporal destination revisit intention: The effects of novelty seeking and satisfaction. Tourism management, 28(2), 580-590. https://doi.org/10.1016/j.tourman.2006.04.024

Jinhua, Y., Yong, L., \& Peng, Z. (2010, May). E-government Evaluation based on Citizen Satisfaction and its Implementation. In 2010 International conference on e-business and e-government (pp. 535-538). IEEE. 10.1109/ICEE.2010.143

Kaisara, G., \& Pather, S. (2009). e-Government in South Africa: e-service quality access and adoption factors.

Kiesler, S., Zdaniuk, B., Lundmark, V., \& Kraut, R. (2000). Troubles with the Internet: The dynamics of help at home. Human-computer interaction, 15(4), 323-351. https://doi.org/10.1207/S15327051HCI1504_2

Korsten, H., \& Bothma, T. J. D. (2005). Evaluating South African government Web sites: 
Methods, findings and recommendations (Part 1). SA Journal of Information Management, 7(2). https://doi.org/10.4102/sajim.v7i3.271

Lam, L. W. (2012). Impact of competitiveness on salespeople's commitment and performance. $\begin{array}{llll}\text { Journal of Business } & \text { Research, 65(9), 1328-1334. }\end{array}$ https://doi.org/10.1016/j.jbusres.2011.10.026

Layne, K., \& Lee, J. (2001). Developing fully functional E-government: A four stage model. $\begin{array}{llll}\text { Government information } & \text { quarterly, } & 18(2), & 136 .\end{array}$ https://doi.org/10.1016/S0740-624X(01)00066-1

Liu, Y., \& Jang, S. S. (2009). Perceptions of Chinese restaurants in the US: what affects customer satisfaction and behavioral intentions?. International Journal of Hospitality Management, 28(3), 338-348. https://doi.org/10.1016/j.ijhm.2008.10.008

MacCallum, R. C., Browne, M. W., \& Sugawara, H. M. (1996). Power analysis and determination of sample size for covariance structure modeling. Psychological methods, 1(2), 130. https://doi.org/10.1037/1082-989X.1.2.130

Macintosh, A., \& Whyte, A. (2006, September). Evaluating how eParticipation changes local democracy. In Proceedings of the eGovernment Workshop (pp. 1-902316).

Martilla, J. A., \& James, J. C. (1977). Importance-performance analysis. Journal of marketing, 41(1), 77-79. https://doi.org/10.1177/002224297704100112

Massey, A. P., Khatri, V., \& Montoya-Weiss, M. M. (2007). Usability of online services: The role of technology readiness and context. Decision Sciences, 38(2), 277-308. https://doi.org/10.1111/j.1540-5915.2007.00159.x

Meuter, M. L., Bitner, M. J., Ostrom, A. L., \& Brown, S. W. (2005). Choosing among alternative service delivery modes: An investigation of customer trial of self-service technologies. Journal of marketing, 69(2), 61-83. https://doi.org/10.1509/jmkg.69.2.61.60759

Meuter, M. L., Ostrom, A. L., Roundtree, R. I., \& Bitner, M. J. (2000). Self-service technologies: understanding customer satisfaction with technology-based service encounters. Journal of marketing, 64(3), 50-64. https://doi.org/10.1509/jmkg.64.3.50.18024

Muir, A., \& Oppenheim, C. (2002). National information policy developments worldwide I: electronic government. Journal of information science, 28(3), 173-186. https://doi.org/10.1177/016555150202800301

Napitupulu, D. and Adiyarta, K., 2019, April. Public Participation Readiness Toward E-Gov 2.0: Lessons from Two Countries. In Proceedings of the 12th International Conference on Theory and Practice of Electronic Governance (pp. 240-243). https://doi.org/10.1145/3326365.3326397

Nelson, R. R. (1994). The co-evolution of technology, industrial structure, and supporting institutions. Industrial and corporate change, 3(1), 47-63. https://doi.org/10.1093/icc/3.1.47

Oh, H. (2000). Diners' perceptions of quality, value, and satisfaction: A practical viewpoint. Cornell Hotel and Restaurant Administration Quarterly, 41(3), 58-66. https://doi.org/10.1177/001088040004100317

Oliver, R. L. (1980). A cognitive model of the antecedents and consequences of satisfaction decisions. Journal of marketing research, 17(4), 460-469. 
https://doi.org/10.1177/002224378001700405

Oliver, R. L. (1999). Whence consumer loyalty? Journal of Marketing. 1999. https://doi.org/10.2307/1252099

Oliver Richard, L. (1997). Satisfaction: A behavioral perspective on the consumer. New York NY: Irwin-McGraw-Hill.

Omar, K., Scheepers, H., \& Stockdale, R. (2011, August). eGovernment service quality assessed through the public value lens. In International Conference on Electronic Government (pp. 431-440). Springer, Berlin, Heidelberg. https://doi.org/10.1007/978-3-642-22878-0_36

Osman, I. H., Anouze, A. L., Irani, Z., Al-Ayoubi, B., Lee, H., Balc1, A., ... \& Weerakkody, V. (2014). COBRA framework to evaluate e-government services: A citizen-centric perspective. Government information quarterly, 31(2), 243-256. https://doi.org/10.1016/j.giq.2013.10.009

Ouellette, J. A., \& Wood, W. (1998). Habit and intention in everyday life: The multiple processes by which past behavior predicts future behavior. Psychological bulletin, 124(1), 54 . https://doi.org/10.1037/0033-2909.124.1.54

Papadomichelaki, X., Magoutas, B., Halaris, C., Apostolou, D., \& Mentzas, G. (2006, September). A review of quality dimensions in e-government services. In International Conference on Electronic Government (pp. 128-138). Springer, Berlin, Heidelberg. https://doi.org/10.1007/11823100_12

Papadomichelaki, X., \& Mentzas, G. (2012). e-GovQual: A multiple-item scale for assessing e-government service quality. Government information quarterly, 29(1), 98-109. https://doi.org/10.1016/j.giq.2011.08.011

Parasuraman, A., Zeithaml, V. A., \& Malhotra, A. (2005). ES-QUAL: A multiple-item scale for assessing electronic service quality. Journal of service research, 7(3), 213-233. https://doi.org/10.1177/1094670504271156

Parasuraman, A., \& Zinkhan, G. M. (2002). Marketing to and serving customers through the Internet: An overview and research agenda. Journal of the academy of marketing science, 30(4), 286-295. https://doi.org/10.1177/009207002236906

Rambe, M. (2017). Performance Analysis of a Government Agency Program Case: Partly Achievement of INSW System.

Reddick, C., \& Norris, D. F. (2013). E-participation in local governments: An examination of political-managerial support and impacts. Transforming Government: People, Process and Policy. https://doi.org/10.1108/TG-02-2013-0008

Reffat, R. (2003). Developing A Successful E-Government. School of Architecture, Design Science and Planning. University Of Sydney.

Saha, P. (2008). Government e-service delivery: identification of success factors from citizens' perspective (Doctoral dissertation, Luleå tekniska universitet).

Samijadi, M. F. (2017). Social media usage in e-government: Evidence from Suriname. Journal of Public Administration and Governance, 7(2), 75-87. https://doi.org/10.5296/jpag.v7i2.11268

Setyono, A., Handoko, L. B., Salam, A., Noersasangko, E., \& Waluyo, D. E. (2019, 
September). Development of Mobile e-Participation System to Enhance e-Government Performance. In 2019 International Seminar on Application for Technology of Information and Communication (iSemantic) (pp. 288-293). IEEE. https://doi.org/10.1109/ISEMANTIC.2019.8884221

Shareef, M. A., Archer, N., Kumar, V., \& Kumar, U. (2010). Developing fundamental capabilities for successful e-government implementation. International Journal of Public Policy, 6(3-4), 318-335. https://doi.org/10.1504/IJPP.2010.035133

Shareef, M. A., Kumar, V., Kumar, U., \& Dwivedi, Y. K. (2011). e-Government Adoption Model (GAM): Differing service maturity levels. Government information quarterly, 28(1), 17-35. https://doi.org/10.1016/j.giq.2010.05.006

Spreng, R. A., \& Page Jr, T. J. (2001). The impact of confidence in expectations on consumer satisfaction. Psychology \& Marketing, 18(11), 1187-1204. https://doi.org/10.1002/mar.1049

Stibbe, M. (2005). E-government security. Infosecurity Today, 2(3), 8-10. https://doi.org/10.1016/S1742-6847(05)70272-X

Stratu-Strelet, D., Gil-Gómez, H., Oltra-Badenes, R., \& Oltra-Gutierrez, J. V. (2021). Critical factors in the institutionalization of e-participation in e-government in Europe: Technology or leadership?. Technological Forecasting and Social Change, 164, 120489. https://doi.org/10.1016/j.techfore.2020.120489

Surjadjaja, H., Ghosh, S., \& Antony, J. (2003). Determining and assessing the determinants of e-service operations. Managing Service Quality: An International Journal. https://doi.org/10.1108/09604520310456708

Tan, C. W., Benbasat, I., \& Cenfetelli, R. T. (2013). IT-mediated customer service content and delivery in electronic governments: An empirical investigation of the antecedents of service quality. MIS quarterly, 77-109. https://doi.org/10.25300/MISQ/2013/37.1.04

Tassabehji, R., Elliman, T., \& Mellor, J. (2007). Generating citizen trust in e-government security: Challenging perceptions. International Journal of Cases on Electronic Commerce (IJCEC), 3(3), 1-17. https://doi.org/10.4018/jcec.2007070101

Thatcher, K. L., Fletcher, K., \& Decker, B. (2008). Communication disorders in the school: Perspectives on academic and social success an introduction. Psychology in the Schools, 45(7), 579-581. https://doi.org/10.1002/pits.20310

Thong, J. Y. (1999). An integrated model of information systems adoption in small businesses. Journal of management information systems, 15(4), 187-214. https://doi.org/10.1080/07421222.1999.11518227

Tomor, Z., Meijer, A., Michels, A., \& Geertman, S. (2019). Smart governance for sustainable cities: findings from a systematic literature review. Journal of urban technology, 26(4), 3-27. https://doi.org/10.1080/10630732.2019.1651178

Venkatesh, V. (1999). Creation of favorable user perceptions: Exploring the role of intrinsic motivation. MIS quarterly, 239-260. https://doi.org/10.2307/249753

Venkatesh, V., \& Davis, F. D. (1996). A model of the antecedents of perceived ease of use: Development and test. Decision sciences, 27(3), 451-481. https://doi.org/10.1111/j.1540-5915.1996.tb00860.x 


\section{Macrothink}

Journal of Public Administration and Governance

ISSN 2161-7104

2021, Vol. 11, No. 2

Venkatesh, V., \& Brown, S. A. (2001). A longitudinal investigation of personal computers in homes: Adoption determinants and emerging challenges. MIS quarterly, 71-102. https://doi.org/10.2307/3250959

Wang, Y. S. (2003). The adoption of electronic tax filing systems: an empirical study. Government Information Quarterly, 333-352. https://doi.org/10.1016/j.giq.2003.08.005

Wimmer, M. A., Chappelet, J. L., Janssen, M., \& Scholl, H. J. (2010). Electronic government. Springer. https://doi.org/10.1007/978-3-642-14799-9

Wirtz, J., \& Bateson, J. E. (1999). Consumer satisfaction with services: integrating the environment perspective in services marketing into the traditional disconfirmation paradigm. Journal of Business research, 44(1), 55-66. https://doi.org/10.1016/S0148-2963(97)00178-1

Yoon, J. H., Kim, K. W., Lee, S. H., \& Kim, J. Y. (2015). A study on factors and measurement methodology on workers' work competence levels for sustainable management in ICT organization. Asia-Pacific Journal of Business Venturing and Entrepreneurship, 10(5), 27-43. https://doi.org/10.16972/apjbve.10.5.201510.27

United Nations (2020) UN E-government survey 2020. Retrieved from https://publicadministration.un.org/egovkb/en-us/Reports/UN-E-Government-Survey-2020

Zaim, S., Turkyilmaz, A., Tarim, M., Ucar, B., \& Akkas, O. (2010). Measuring customer satisfaction in Turk Telekom Company using structural equation modeling technique. Journal of global strategic management, 7(2010), 89-99. https://doi.org/10.20460/JGSM.2010415842

Zeithaml, V. A., Berry, L. L., \& Parasuraman, A. (1996). The behavioral consequences of service quality. Journal of marketing, 60(2), 31-46. https://doi.org/10.1177/002224299606000203

Zheng, Y., \& Schachter, H. L. (2017). Explaining citizens' E-participation use: The role of perceived advantages. Public Organization Review, 17(3), 409-428. https://doi.org/10.1007/s11115-016-0346-2

\section{Copyright Disclaimer}

Copyright for this article is retained by the author(s), with first publication rights granted to the journal.

This is an open-access article distributed under the terms and conditions of the Creative Commons Attribution license (http://creativecommons.org/licenses/by/4.0/). 